\title{
SKRINING FITOKIMIA DAN UJI AKTIVITAS ANTIBAKTERI EKSTRAK ETANOL DAUN RACUN AYAM (Brucea javanica [L.] Merr.) ASAL KALIMANTAN SELATAN
}

\author{
Sutomo $^{1 *}$, Fahriah ${ }^{1}$, Arnida $^{2}$ \\ ${ }^{1}$ Program Studi Farmasi Fakultas MIPA Universitas Lambung Mangkurat \\ ${ }^{2}$ Pusat Studi Obat Berbasis Bahan Alam Universitas Lambung Mangkurat \\ *Email: sutomo01@ulm.ac.id
}

Artikel diterima: 29 September 2020; Disetujui: 16 Maret 2021

DOI: https://doi.org/10.36387/jiis.v6i1.607

\begin{abstract}
ABSTRAK
Tumbuhan racun ayam adalah salah satu tumbuhan yang buahnya memiliki beberapa aktivitas salah satunya adalah sebagai antibakteri. Penelitian ini bertujuan untuk menetapkan aktivitas antibakteri ekstrak etanol daun racun ayam. Ekstraksi dilakukan dengan metode maserasi menggunakan pelarut etanol. Uji aktivitas antibakteri dilakukan terhadap bakteri $S$. aureus, E. coli, dan $P$. aeruginosa dengan metode difusi cakram pada konsentrasi 80, 100, dan 120 ppm. Hasil penelitian diperoleh ekstrak etanol daun $B$. javanica memiliki zona hambat paling besar pada E. coli dengan nilai diameter zona hambat pada $80,100,120 \mathrm{ppm}$ yaitu $11,7 \mathrm{~mm}$, $14,5 \mathrm{~mm}$ dan $19,67 \mathrm{~mm}$. Zona hambat pada $S$. aureus hanya terlihat pada konsentrasi 100 dan 120 ppm dengan diameter zona hambat $1,17 \mathrm{~mm}$ dan $2,17 \mathrm{~mm}$, sedangkan pada $P$. aeruginosa tidak memiliki nilai zona hambat. Hasil analisis statistik yaitu menunjukkan signifikansi nilai diameter zona hambat pada bakteri $E$. coli mulai 80 ppm dengan nilai sig 0,034 karena sig $<0,05$ maka berbeda signifikan dengan kontrol negatif. Bakteri $S$. aureus yang memiliki nilai sig $<0,05$ hanya pada $100 \mathrm{ppm}$ dan $120 \mathrm{ppm}$. Bakteri $P$. aeruginosa memiliki nilai sig $>0,05$ yaitu tidak berbeda signifikan terhadap semua konsentrasi.
\end{abstract}

Kata kunci: Cakar ayam; Brucea javanica; Skrining; Ekstrak; antibakteri

\begin{abstract}
Racun ayam is one of the plants which has several activities in its fruits, one of which is an antibacterial. This study aims to determine the antibacterial activity of ethanol extract of racun ayam leaves. The extraction was done by maceration method using ethanol as a solvent. Antibacterial activity assay was carried out on $S$. aureus, E. coli, and P. aeruginosa bacteria by disk diffusion method at the concentrations of 80,100 , and $120 \mathrm{ppm}$. The results showed that the ethanol extract of B. javanica leaves had the greatest inhibition zone on E. coli with inhibition zone diameter values at 80,100, and $120 \mathrm{ppm}$ were $11.7 \mathrm{~mm}, 14.5 \mathrm{~mm}$ and $19.67 \mathrm{~mm}$ respectively. Inhibition zones in S. aureus could only be seen at 100 and 120 ppm which had inhibition zone diameters at $1.17 \mathrm{~mm}$ and $2.17 \mathrm{~mm}$ respectively, whereas in P. aeruginosa they did not have any inhibitory zone values. The results of
\end{abstract}


statistical analysis showed a significance of the inhibition zone diameter values of E. coli bacteria starting at 80 ppm with a sig value of 0.034 . Due to a sig value was $<0.05$, it was categorized as significantly different from the negative control. The bacteria of $S$. aureus which had $<0.05$ for sig values only found on 100 ppm and 120 ppm. Bacteria P. aeruginosa which had sig value >0.05 was not significantly different at all concentrations.

Keywords: Cakar ayam; Brucea javanica; screening; extract; antibacterial

\section{PENDAHULUAN}

Racun ayam (Brucea javanica

[L.] Merr.) merupakan salah satu tumbuhan obat tradisional dalam pengobatan penyakit infeksi. Buah masak B. javanica yang telah dikeringkan banyak digunakan untuk mengobati penyakit infeksi pada saluran pencernaan dan lainnya (WHO, 1999). Daun dari B. javanica secara empiris telah digunakan suku Dayak Meratus untuk mengobati penyakit kulit seperti kurap dan gatalgatal. Aktivitas antibakteri dari sari buah tumbuhan ini juga telah dibuktikan pada beberapa bakteri seperti Salmonella, Shigella, dan Vibriocholerae spp (Sornwatana et al., 2013).

Penyakit infeksi merupakan jenis penyakit yang paling banyak dialami oleh penduduk Indonesia. Penyebab dari infeksi tersebut adalah mikroba pathogen seperti bakteri (Radji, 2011). Bakteri adalah mikroorganisme bersel tunggal dengan ukuran panjang 0,5-10 $\mu \mathrm{m}$ dan lebar 0,5-2,5 $\mu \mathrm{m}$ (Arisandi et al., 2017). Jenis bakteri patogen yang sering menyebabkan infeksi yaitu bakteri Staphylococcus aureus, Escherichia coli, dan Pseudomonas aeruginosa (Gibson, 1996 ; Djide \& Sartini, 2008). Bakteri S. aureus adalah gram positif berbentuk kokus, sedangkan bakteri $P$. aeruginosa dan bakteri E. coli merupakan gram negatif (Kayser et al., 2005; Melliawati, 2009; Pelcjar, 2008). S. aureus dapat menyebabkan infeksi pada kulit dan jaringan lunak seperti pneumonia, osteomielitis, meningitis, dan endocarditis. E. coli merupakan flora normal pada saluran pencernaan tubuh manusia namun dapat menjadi patogen apabila berpindah dari habitat normalnya (Bartlett et al., 2010 ; Melliawati, 2009). S. aureus diketahui telah resisten terhadap beberapa antibiotik antara lain 
golongan $\beta$ laktamase, metisilin, nafsilin, oksasilin, dan vankomisin, sedangkan $P$. aeruginosa resisten paling tidak terhadap 3-antimikroba yaitu kelas $\beta$-laktam, carbapenem, dan aminoglikosida (Sari, 2012; Jawetz et al., 2008).

Banyaknya resistensi bakteri terhadap antibiotik memacu peneliti untuk menemukan obat baru dari bahan alam. Seperti yang telah diketahui tumbuhan B. javanica telah banyak digunakan sebagai obat tradisional untuk penyakit infeksi dan penyakit lainnya. Telah banyak penelitian mengenai buah dan biji dari tumbuhan tersebut namun masih terbatas untuk bagian daunnya. Peneliti tertarik untuk melakukan skrining fitokimia dan uji aktivitas antibakteri ekstrak daun B. javanica terhadap penghambatan bakteri $S$. aureus, E. coli, dan P. aeruginosa.

\section{METODE PENELITIAN}

\section{Tempat Penelitian}

Penelitian dilaksanakan di Laboratorium FarmakognosiFitokimia Program Studi Farmasi Fakultas MIPA Universitas Lambung Mangkurat Banjarbaru serta Balai
Riset dan Standardisasi Industri (Baristan) Banjarbaru.

\section{Alat dan Bahan}

Alat yang digunakan pada penelitian ini meliputi autoclave Tomy (sx-500), alat-alat gelas (Pyrex, Iwaki), bejana maserasi, bunsen, cawan petri, cawan porselin, inkubator (Memmert), laminary air flow (Daihan Labtech), lemari steril (Ellitech), oven (Thermoline), timbangan analitik (AND GF 3000), lemari pengering (Lokal), pinset, propipet, rak tabung, stamper, jangka sorong, waterbath (Memmert).

Bahan-bahan yang digunakan dalam penelitian yaitu daun $B$. javanica., aquades, etanol 96\%, kertas saring Whatman 42, pereaksi Dragendorff, Mayer, LiebermannBuchard, $\mathrm{HCl}$, kloroform, asam asetat glasial, gelatin, asam sulfat, barium klorida, Nutrient Agar (NA), siprofloksasin, biakan bakteri $S$. aureus ATCC 25923, E. coli ATCC 25929 dan P. aeruginosa ATCC 9027 koleksi Laboratorium Baristan.

\section{Determinasi Tumbuhan}

Tumbuhan B. javanica dilakukan determinasi di Kebun Raya Banua (KRB) Banjarbaru. 


\section{Pengambilan dan Pengolahan Sampel}

Preparasi dimulai dari pengumpulan sampel yang diambil dari KRB Banjarbaru berupa daun $B$. Javanica yang sudah dewasa, dilakukan sortasi basah dengan memilih bagian daun yang segar dan tidak rusak. Daun dicuci dengan menggunakan air mengalir dan dikeringkan dalam lemari pengering suhu $50^{\circ} \mathrm{C}$. Dilakukan sortasi kering dan diperkecil ukurannya menjadi serbuk kasar (mesh 14).

\section{Pembuatan Ekstrak Etanol daun Brucea javanica}

Sampel dimaserasi menggunakan pelarut etanol $96 \%$. Sebanyak 750 gram serbuk daun $B$. javanica ditimbang dan ditambahkan etanol 96\% (Perbandingan 1: $17 \mathrm{~b} / \mathrm{v}$ ) dan dilakukan 3 kali replikasi. Setiap $1 \times 24$ jam cairan penyari disaring dan diganti dengan yang baru. Ekstrak diuapkan dengan menggunakan rotary evaporator dengan suhu $60^{\circ} \mathrm{C}$. Ekstrak tersebut kemudian dikentalkan di atas waterbath dengan suhu $60^{\circ} \mathrm{C}$ hingga didapatkan bobot tetap. Rendemen yang diperoleh dihitung menggunakan rumus: $\frac{\text { bobot ekstrak }(\mathrm{g})}{\text { bobot sampel kering }(\mathrm{g})} \times 100 \%$

\section{Uji kualitatif pelarut pada ekstrak}

Ekstrak etanol ditimbang 1 gram, kemudian dimasukkan ke dalam tabung reaksi, ditambahkan 1 mL larutan $\mathrm{KMnO}_{4}$ dan 5 tetes $\mathrm{H}_{2} \mathrm{SO}_{4}$ 2 N. Tidak munculnya warna kuning kecoklatan pada sampel menandakan tidak adanya kandungan alkohol pada sampel (Kemenkes RI, 2014).

\section{Skrining fitokimia}

1. Uji flavonoid, alkaloid, tanin, dan fenolik

Ekstrak kental yang telah dilarutkan dalam etanol pa ditambahkan serbuk $\mathrm{Mg}$ dan $\mathrm{HCl}$ pekat untuk uji flavonoid, pereaksi Mayer dan Dragendorf untuk uji alkaloid, larutan gelatin $5 \mathrm{~mL} 1 \%$ untuk uji tanin, 3 tetes $\mathrm{FeCl}_{3} \quad 2 \%$ untuk uji fenolik. Terbentuknya warna orange, merah, atau kuning dinyatakan postif mengandung flavanoid (Depkes RI, 2008). Pereaksi Mayer memberikan endapan putih dan pereaksi Dragendorff memberikan endapan berwarna jingga menunjukkan adanya alkaloid (Prameswari \& 
Widjanarko, 2014). Adanya endapan putih menunjukkan adanya tanin. Terbentuknya warna menjadi hijau, merah, biru atau biru tua menunjukan adanya senyawa fenolik (Harborne, 1987)

2. Uji saponin

Uji saponin dilakukan dengan menimbang ekstrak $5 \mathrm{mg}$ ditambahkan aquades $10 \mathrm{~mL}$ dan dikocok kuat-kuat. Terbentuknya busa yang stabil menunjukkan adanya senyawa saponin (Savithramma et al., 2011).

3. Uji steroid/triterpenoid

Ekstrak kental yang telah dilarutkan dalam kloroform ditambahkan $2 \mathrm{~mL}$ asam asetat anhidrat dan $2 \mathrm{~mL} \mathrm{H}_{2} \mathrm{SO}_{4}$ pekat melalui dinding tabung. Terbentuknya warna biru atau hijau menunjukkan adanya steroid dan jika terbentuk warna ungu-merah adanya triterpenoid (Harborne, 1987).

Pembuatan standar kekeruhan larutan (larutan Mc Farland)

$\begin{array}{llll}\text { Larutan } & \mathrm{H}_{2} \mathrm{SO}_{4} & 0,36 & \mathrm{~N}\end{array}$ sebanyak 99,5 $\mathrm{mL}$ dicampurkan dengan larutan $\mathrm{BaCl}_{2} \cdot 2 \mathrm{H}_{2} \mathrm{O} \quad 1,175 \%$ sebanyak 0,5 mL. Campuran dikocok sampai terbentuk larutan yang keruh. Kekeruhan ini dipakai sebagai standar kekeruhan suspensi bakteri uji dan digunakan tidak lebih dari 15 menit (Victor, 1980).

\section{Pembuatan suspensi bakteri uji}

Bakteri uji yang telah diinokulasi diambil dengan ose steril lalu disuspensikan ke dalam tabung yang berisi $2 \mathrm{~mL}$ larutan $\mathrm{NaCl} 0,9 \%$ hingga di peroleh kekeruhan yang sama dengan standar kekeruhan larutan Mc. Farland. Perlakuan yang sama dilakukan pada setiap jenis bakteri uji (Mpila et al., 2018).

\section{Pembuatan larutan Na-CMC}

Larutan $\mathrm{Na}-\mathrm{CMC}$ 0,5\% dibuat dengan cara menimbang $500 \mathrm{mg}$ serbuk Na-CMC dan melarutkan dengan aquades panas suhu $70^{\circ} \mathrm{C}$. Serbuk Na-CMC dimasukkan sedikit demi sedikit sambil diaduk sampai larutan berwarna bening. Larutan diencerkan dengan aquadest dalam labu ukur hingga $100 \mathrm{~mL}$ (Mpila et al., 2018).

\section{Pembuatan larutan kontrol positif}

Kontrol positif dibuat menggunakan tablet Ciprofloxacin $500 \mathrm{mg}$. Tablet digerus dan dibuat 
larutan 100 ppm dengan cara melarutkan $1 \mathrm{mg}$ ciprofloxacin dan dilarutkan dalam larutan Na-CMC 0,5\% $10 \mathrm{~mL}$. Larutan diencerkan menjadi 50 ppm dengan cara mengambil $5 \mathrm{~mL}$ larutan $100 \mathrm{ppm}$ dan ditambahkan Na-CMC 0,5\% hingga $10 \mathrm{~mL}$ (Prasdiyanti, 2018).

\section{Pembuatan larutan uji}

Larutan stok dengan konsentrasi 120 ppm dibuat dengan cara menimbang $12 \mathrm{mg}$ ekstrak dan dilarutkan dalam $100 \mathrm{~mL} \mathrm{Na-CMC}$ 0,5\%. Dari larutan stok tersebut dilakukan pengenceran untuk mendapatkan larutan uji 100 ppm dan 80 ppm (Mpila et al., 2018).

\section{Pembuatan media uji}

Media uji dibuat dengan menimbang 1,8 gram Nutrient Agar (NA), lalu dilarutkan dalam $90 \mathrm{~mL}$ aquades $(20 \mathrm{~g} / 1000 \mathrm{~mL})$. Media dihomogenkan dengan stirer di atas penangas air sampai mendidih. Media disterilkan dalam autoclave pada suhu $121^{\circ} \mathrm{C}$ selama 15 menit, kemudian didinginkan sampai suhu \pm 45-50 ${ }^{\circ} \mathrm{C}$. Media dimasukkan ke dalam cawan petri sebanyak $15 \mathrm{~mL}$ per cawan (Mpila et al., 2018).

\section{Uji aktivitas antibakteri ekstrak etanol daun Brucea javanica}

Uji aktivitas antibakteri dilakukan dengan difusi cakram menggunakan media agar yang diolesi suspensi bakteri uji dan diletakkan kertas cakram yang sudah dicelupkan larutan ektrak. Ekstrak etanol daun B. javanica konsentrasi 80 ppm, 100 ppm, 120 ppm, kontrol positif dan kontrol negatif ppm dimasukkan pada cawan petri pertama, kedua dan ketiga dengan 4 titik melingkar dan 1 titik di bagian tengah. Setelah itu diinkubasi selama 24 jam. Pengamatan penghambatan dilakukan setelah 1 x 24 jam masa inkubasi (Vandepitte et al, 2005).

\section{Analisis Data}

Apabila konsentrasi yang diberikan memiliki daya hambat yang besar maka akan menimbulkan angka diameter zona hambat yang besar pula (Davis \& Stout, 1971). Adapun rumus untuk menghitung zona hambat yaitu :

$$
\text { Zona hambat }=\frac{\mathrm{d} 1+\mathrm{d} 2}{2}-\mathrm{X}
$$

Keterangan :

$\mathrm{d} 1=$ Diameter vertikal zona bening pada media (mm)

$\mathrm{d} 2=$ diameter horizontal zona bening pada media $(\mathrm{mm})$

$\mathrm{X}=\operatorname{Diameter}$ cakram $(6 \mathrm{~mm})$ 
Kategori hasil luas zona hambat yaitu >20 mm dikategorikan sangat kuat, 11-20 mm dikategorikan kuat, 6-10 mm dikategorikan sedang dan $<5 \mathrm{~mm}$ dikategorikan lemah (Susanto et al., 2012). Analisis deskriptif dilakukan untuk mengetahui nilai rata-rata zona hambat dan analisis program SPSS untuk mengetahui signifikasi pada masing-masing perlakuan.

\section{HASIL DAN PEMBAHASAN}

\section{Ekstraksi}

Dari 750 g serbuk simplisia yang diekstraksi didapatkan ekstrak kental sebanyak 237,15 g (31,62\%). Ekstrak berwarna hijau tua dengan rasa agak pahit.
Tabel 1. Hasil skrining fitokimia ekstrak etanol $96 \%$ daun B. javanica

\begin{tabular}{ccc}
\hline No & Uji & Hasil \\
\hline 1. & Alkaloid & $(-)$ \\
2. & Flavonoid & $(+)$ \\
3. & Tannin & $(-)$ \\
4. & Fenolik & $(+)$ \\
5. & Steroid & $(+)$ \\
6. & Triterpenoid & $(-)$ \\
7. & Saponin & $(+)$ \\
\hline
\end{tabular}

Keterangan

(+): Mengandung senyawa uji

(-) : Tidak mengandung senyawa uji

\section{Skrinning Fitokimia}

Skrining fitokimia dilakukan untuk mengidentifikasi kandungan metabolit sekunder dalam ekstrak etanol daun B. javanica, dimana beberapa metabolit sekunder berpotensi sebagai antibakteri. Hasil skrining fitokimia disajikan pada Tabel 1.

Tabel 2. Hasil diameter rata-rata zona hambat dan standar deviasi ekstrak etanol 96\% daun B. javanica terhadap bakteri S. aureus, E. coli, dan P. aeruginosa

\begin{tabular}{cccccc}
\hline \multirow{2}{*}{ Bakteri } & $\mathbf{5} \mathbf{~ p p m}$ & $\mathbf{1 0 0} \mathbf{~ p p m}$ & $\mathbf{1 2 0} \mathbf{~ p p m}$ & $\mathbf{K}(+)$ & $\mathbf{K}(-)$ \\
\cline { 2 - 6 } & $0 \pm 0$ & $1,17 \pm 0,28$ & $2,17 \pm 1,25$ & $24,67 \pm 1,15$ & $0 \pm 0$ \\
S. aureus & $11,17 \pm$ & $14,5 \pm 1,32$ & $19,67 \pm 1,60$ & $27,5 \pm 1,73$ & $0 \pm 0$ \\
E.coli & 0,57 & $0 \pm 0$ & $0 \pm 0$ & $26,67 \pm 0,57$ & $0 \pm 0$ \\
$\begin{array}{c}P . \\
\text { aeruginosa }\end{array}$ & $0 \pm 0$ & $0 \pm 0$ & &
\end{tabular}

\section{Penentuan Diameter Zona Hambat}

$\begin{array}{cll}\text { Hasil } & \text { yang } & \text { didapat } \\ \text { menunjukkan } & \text { bahwa } & \text { dengan }\end{array}$

konsentrasi yang sama diameter zona hambat paling besar terdapat pada bakteri E. coli (kategori kuat), diikuti bakteri S. aureus (kategori lemah), dan pada bakteri $P$. aeruginosa tidak memiliki zona hambat konsentrasi. Hasil diameter rata-rata zona hambat terhadap bakteri uji, kontrol positif, dan kontrol negatif dapat dilihat pada 


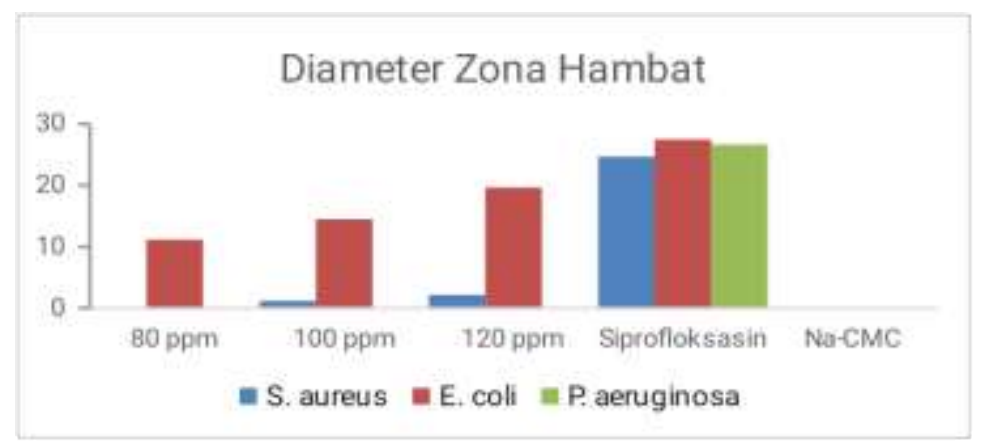

Gambar 1. Hasil diameter rata-rata zona hambat ekstrak etanol $96 \%$ daun $B$. javanica terhadap bakteri S. aureus, E. coli, dan P. aeruginosa

\section{Analisis dengan Uji SPSS}

Analisis statistik terhadap ketiga bakteri uji yaitu analisis statistik meliputi uji normalitas dan uji homogenitas serta uji lanjutan dengan uji Mann Whitney. Pada bakteri $S$. aureus pada konsentrasi 100 ppm dengan nilai rata-rata 1,17 mm memiliki nilai sig 0,043 dengan kontrol positif. Dapat disimpulkan bahwa konsentrasi daya hambat minimum untuk uji aktivitas antibakteri ekstrak etanol daun $B$. javanica terhadap bakteri S. aureus yaitu pada 100 ppm dengan nilai ratarata $1,17 \mathrm{~mm}$ berbeda signifikan terhadap kontrol positif jauh lebih lemah dimana pada konsentrasi 20 ppm menghasilkan diameter zona hambat $24,67 \mathrm{~mm}$. Pada bakteri $E$. coli pemberian sampel pada konsentrasi 100 dan 120 ppm memiliki aktivitas yang signifikan terhadap kontrol negatif, sedangkan pada konsentrasi 80 ppm belum signifikan. Namun hasil aktivitas antibakteri terhadap bakteri $E$. coli hingga konsentrasi 120 ppm masih belum sebanding dengan kontrol positif konsentrasi $20 \mathrm{ppm}$. Untuk bakteri $P$. aeruginosa yang diberikan pada konsentrasi 80, 100, dan 120 ppm tidak berbeda signifikan dengan kontrol negatif dan berbeda signifikan dengan kontrol positif. Berdasarkan hasil analisis tersebut dapat disimpulkan bahwa eksrak etanol daun B. javanica tidak memiliki aktivitas terhadap bakteri $P$. aeruginosa.

\section{KESIMPULAN}

Berdasarkan penelitian ini dapat diambil kesimpulan yaitu :

1. Hasil skrinning fitokimia yaitu ekstrak etanol daun racun ayam 
memiliki kandungan saponin, fenolik, steroid, dan flavonoid.

2. Hasil penelitian diperoleh ekstrak etanol daun $B$. javanica memiliki zona hambat paling besar pada $E$. coli dengan nilai diameter zona hambat pada $80,100,120$ ppm yaitu $11,7 \mathrm{~mm}, 14,5 \mathrm{~mm} \& 19.67 \mathrm{~mm}$. Zona hambat pada $S$. aureus hanya terlihat pada konsentrasi 100 dan 120 ppm dengan diameter zona hambat $1,17 \mathrm{~mm}$ dan $2,17 \mathrm{~mm}$, sedangkan pada $P$. aeruginosa tidak memiliki nilai zona hambat.

\section{UCAPAN TERIMA KASIH}

Ucapan terimakasih kepada LPPM ULM dan Kebun Raya Banua atas semua Suport dalam penelitian, laboratorium farmasi ULM serta Balai Riset dan Standardisasi Industri Banjarbaru sehingga penelitian ini dapat diselesaikan.

\section{DAFTAR PUSTAKA}

Arisandi, A., B. Tamam \& R. Yulian. 2017. Jumlah Koloni pada Media Kultur Bakteri yang Berasal dari Thallus dan Perairan Sentra Budidaya Kappaphycus di Sumenep Alvarezii. Jurnal Ilmiah Perikanan dan Kelautan. 9 : 5764.

Bartlett., Allison., Hulten \& G. Kristina. 2010. Staphylococcus aureus Pathogenesis Secretion
Systems, Adhesins, and Invasins. The Pediatric Infectious Disease. 9 : 860-861.

Davis, W.W \& Stout, T.R. 1971. Disc Plate Methods of Microbiological Antibiotic Assay. Microbiology. 4 : 659665.

Depkes RI. 2008. Farmakope Herbal Indonesia Edisi Pertama. Departemen Kesehatan Republik Indonesia, Jakarta.

Djide \& Sartini. 2008. Dasar-Dasar Mikrobiologi Farmasi. Lephas, Makasar.

Gibson, J. M. 1996. Mikrobiologi dan Patologi Modern Untuk Perawat. EGC, Jakarta.

Harborne, J. B. 1987. Metode Fitokimia: Penuntun Cara Modern Menganalisis Tumbuhan. Terbitan Kedua. Penerbit ITB, Bandung

Jawetz, E., J. L. Melnick \& E. A. Adelberg. 2008. Mikrobiologi Kedokteran, Edisi Ke-23. EGC, Jakarta.

Kayser, F., K. Bienz., J. Eckert \& R. Zinkernagel. 2005. Color Atlas of Medical Microbiology, New York.

Kemenkes RI. 2014. Farmakope Herbal Indonesia Edisi I. Kementerian Kesehatan Republik Indonesia, Jakarta.

Melliawati, R. 2009. Escherichia coli dalam Kehidupan Manusia. Biotrends. 4 : 10-14.

Mpila, D., F. Fatimawali \& W. Wiyono. 2018. Uji Aktivitas Antibakteri Ekstrak Etanol Daun Mayana (Coleus 
Atropurpureus [L] Benth)

Terhadap Staphylococcus aureus, Escherichia Coli Dan Pseudomonas Aeruginosa Secara In-Vitro. Pharmacon.

Pelczar. Michael J. and Chan. E.C.S. 2008. Dasar-Dasar Mikrobiologi, Terjemahan oleh Hadioetomo, Ratna sari dkk. Universitas Indonesia: Jakarta.

Prameswari, O. M \& S. B. Widjanarko. 2014. Uji Efek Ekstrak Air Daun Pandan Wangi terhadap Penurunan Kadar Glukosa Darah dan Histopatologi Tikus Diabetes Mellitus. Jurnal Pangan dan Agroindustri. 2: 16-27.

Prasdiyanti, N. C. 2018. Uji Aktivitas Antibakteri Fraksi dari Ekstrak Kloroform Daun Piper crocatum Ruiz \& Pav. terhadap Staphylococcus aureus Resisten Ampicillin. Skripsi Fakultas Farmasi Universitas Sanata Dharma, Yogyakarta.

Radji, M. 2011. Mikrobiologi. Buku Kedokteran ECG, Jakarta.

Sari, N. I. 2012. Pseudomonas aeruginosa, Penyebab Infeksi Nosokomial. Fakultas Sains dan Teknologi UAI

Savithramma, N., M. L. Rao \& D. Suhrulatha. 2011. Screening of Medicinal Plants for Secondary Metabolites. Middle-East Journal of Scientific Research. $8: 79-584$.

Susanto, D., Sudrajat \& R. Ruga. 2012. Studi Kandungan Bahan Aktif Tumbuhan Meranti Merah (Shorea leprosula Miq) sebagai Sumber Senyawa Antibakteri. 2 : 1-5.

Sornwatana, T., Roytrakul, S., Wetprasit, N \& Ratanapo, S. 2013. Brucin, an antibacterial peptide derived from fruit protein of fructus Bruceae, Brucea javanica (L.) Merr. Soc Appl Microbiol. 2 :129-36.

Vandepitte. 2005. Prosedur Laboratorium Dasar untuk Bakteriologis Klinis. Edisi 2. Buku Kedokteran EGC, Jakarta.

Victor, L. 1980. Antibiotics in Laboratory Test. The Williams and Wilkins Company, USA.

World Health Organization. 1999. WHO monographs on selected medicinal plants Radixglycyrrhizae. Essent Med Heal Prod Inf Portal. 1:183-94. 